\title{
超伝導加速空洞用高純度ニオブの再結晶挙動と集合組織
}

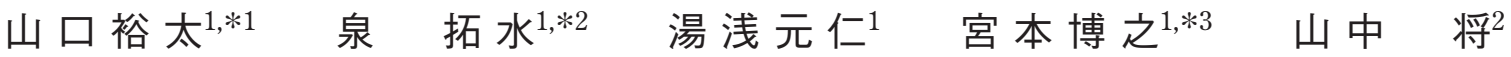 \\ 1 同志社大学理工学部機械系学科 \\ 2高エネルギー加速器研究機構機械工学センター
}

J. Japan Inst. Met. Mater. Vol. 82, No. 7 (2018), pp. 262-268

(C) 2018 The Japan Institute of Metals and Materials

\section{Recrystallization Behavior and Texture of High-Purity Niobium for SRF Cavity}

Yuta Yamaguchi ${ }^{1, * 1}$, Takumi Izumi ${ }^{1, * 2}$, Motohiro Yuasa ${ }^{1}$, Hiroyuki Miyamoto ${ }^{1, * 3}$ and Masashi Yamanaka $^{2}$

${ }^{1}$ Department of Mechanical Engineering, Doshisha University, Kyotanabe 610-0394
${ }^{2}$ Mechanical Engineering Center, High Energy Accelerator Research Organization (KEK), Tsukuba 305-0801

Deformation and recrystallization behavior of pure niobium was investigated in order to clarify the origin of its low hydroformability despite its high ductility comparable with pure iron. Pure niobium exhibited lower strain hardening in cold rolling compared with pure iron. Furthermore, in post-deformation annealing, the hardness of niobium decreased monotonously with increasing temperature, and a typical sharp drop by recrystallization was not evident. This softening behavior was contrasted with the pure iron. It is suggested that niobium exhibits the so-called in-situ recrystallization because of its low elastic modulus and low accumulative plastic strain energy. The low hydro-formability of pure niobium sheets or tubes can be caused by its low strain hardening and in-situ recrystallization which is associated with this recovered residual rolled texture. [doi:10.2320/jinstmet.J2018010]

(Received February 13, 2018; Accepted April 3, 2018; Published May 11, 2018)

Keywords: pure niobium, strain hardening, texture, in-situ recrystallization, elastic modulus, SRF cavity

\section{1. 緒言}

電子・陽電子の衝突による物理現象を観測する国際リニア コライダー (ILC) 計画では, 高純度ニオブ製の扁平球状の空 洞セルが連結した超伝導 9 セル加速器空洞が約16000個使用さ れる1,2). 加速器空洞は高純度ニオブ板をお椀状にプレス成形 し, 二つの成形品を電子ビーム溶接によりつき合わせて接合 して単一セルとし，これを連結して製造している3 . 一方，製 造コスト低減を目的に, 長尺の高純度ニオブ管から液圧成形 により, 多数の空洞セルが連結した加速器空洞を一括で製造 する方法の研究が行われている ${ }^{1,2)}$ 。この成形法では液圧成形 と中間熱処理を数段階に分けて，金型を変えながら順次成形 が行われる。このため従来法に比較して生産性が飛躍的に高 くなる一方で,ささらに高いバルジ成形性が要求される ${ }^{4,5)}$. し かし高純度ニオブは液圧成形に対する成形性が不十分である ことが課題となっている. ニオブは BCC 構造であり, かつ 融点から室温まで変態点をもたないため, 同じ性質を持つ フェライト系ステンレス鋼から予想して, 加工後の熱処理で は回復が進行し再結晶がしにくいことが考えられる。このた め, 一次素材である板や管は, その溶解時の粗大粒を継承し

\footnotetext{
*1 同志社大学大学院生, 現在：(株) 小松製作所 (Graduate Student, Doshisha University, Present address: Komatsu Ltd.)

*2 同志社大学学生 (Undergraduate Student, Doshisha University)

*3 Corresponding author, E-mail: hmiyamot@mail.doshisha.ac.jp
}

た不均一な加工組織・結晶方位が残留した回復組織となりや すいことが予想される ${ }^{6,7)}$. 例えばフェライト系ステンレス鋼 の場合, 変態点を持たないために粗大な凝固組織が成長して, その後の加工熱処理後に残留したコロニーと呼ばれる類似方 位をもつ結晶粒群が圧延方向に形成し, 一次成形品である板 や管の成形性の低下や成形時に現れるしわ状欠陥であるリジ ングの原因となっている ${ }^{8-10)}$.

ニオブのもう一つの特徴はヤング率が $105 \mathrm{GPa}$ と非常に低 く, 鉄の半分程度しかないことである (Fig. 1) ${ }^{11)}$. 一般的に金 属のヤング率は融点にほぼ相関して高くなるが, ニオブは融 点が $2793 \mathrm{~K}$ の高融点であるにも関わらず, そのヤング率は 非常に低い。低いヤング率は加工硬化性の低下を通してバル

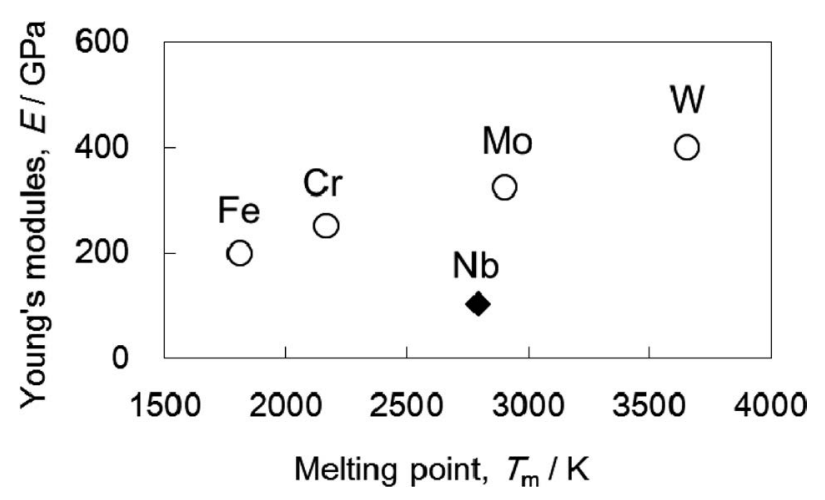

Fig. 1 Relationship between Young's modules and melting point of BCC metals. 
ジ成形性を低下させる直接的な原因となるだけでなく，再結 晶の駆動力である転位の自己エネルギーを低下させるため, 再結晶組織やその集合組織の形成に影響することが予想され る12-14). このように純ニオブは鉄や炭素鋼に比べて再結晶組 織や集合組織が非常に得にくい材料であることが予想される が, ニオブは希少金属であることから，これまで合金元素と 利用されることが多いため, 構造材料としての再結晶挙動や 成形性に関する研究は非常に少ない.

そこで本研究では, 高純度ニオブの上記の特徴を念頭に冷 間圧延および焼鈍時のミクロ組織・集合組織の特徵と軟化機 構を鉄との違いに着目して明らかにすることを目的とした。

\section{2. 実 験 方 法}

(株)アルバックより提供された寸法 $3.5^{\mathrm{t}} \times 120^{\mathrm{w}} \times 400^{\mathrm{l}} \mathrm{mm}$ の 高純度ニオブ板(純度 $99.99 \%$ ，RRR464)を供試材として用い た. 化学組成を Table 1 に示す。 またニオブとの比較材料と して(株)ニラコ製の寸法 $5.0^{\mathrm{t}} \times 100^{\mathrm{w}} \times 100^{1} \mathrm{~mm}$ の高純度鉄板 (純度 $99.99 \%$ )を用いた。供試材の加工硬化能を評価するため に初期ひずみ速度 $1.7 \times 10^{-4} \mathrm{~s}^{-1}$ 引張試験を行った。 引張試験片 は JIS 5 号試験片の $1 / 5$ サイズのものとし, ワイヤーカット放 電加工により切り出した

本研究では, 圧延加工後, 熱処理を行うことによりニオブ の変形・再結晶挙動を評価した。供試材を $3.5^{\mathrm{t}} \times 50^{\mathrm{w}} \times 100^{1} \mathrm{~mm}$ の寸法で切り出し, 井本特殊治金(株)の 2 段圧延機を用いて 冷間圧延を行った。初期板厚は $3.5 \mathrm{~mm}$ であり，厚さ 0.175 $\mathrm{mm}$ (圧延率 $95 \%$ ) まで冷間圧延を行った。 以下では冷間圧延 後の試料を冷延材とし, 圧延方向を $\mathrm{RD}$, 軸方向を $\mathrm{TD}$, ロー ルと接している表面の方向を ND と呼ぶ. 冷延材の再結晶挙 動を評価するために, 赤外線電気炉を用いて 623 ～ 1173 K $(50$ $\mathrm{K}$ 刻み)の各温度で $120 \mathrm{~s}$ 保持したのちに炉冷する焼鈍熱処理 を行った．以下，熱処理後の冷延材を焼鈍材とする. 冷延材, 焼鈍材の硬さはビッカース硬さ試験により評価した。試験は 荷重 $2.94 \mathrm{~N}$ とし, 保持時間は $15 \mathrm{~s}$ で試料の TD 面に対して 行った. 各試料について10ヶ所測定し, その平均值をビッ カース硬さとして採用した。

冷延材, 焼鈍材の組織観察は光学顕微鏡を用いて行った. 各試料の TD 断面を観察面とし，エメリー紙＃80〜 \#2000で湿 式研磨し, ダイヤモンド研磨剤と OPS を用いたバフ研磨を行 い鏡面仕上げした．その後ニオブに対してはフッ化水素酸 10 $\mathrm{mL}$, 硝酸 $20 \mathrm{~mL}$ の混合溶液, 鉄に対してはナイタール液(エ 夕ノール $10 \mathrm{~mL}$, 硝酸 1 ～ $2 \mathrm{~mL}$ の混合溶液)を用いてエッチ ングを行い, 直ちに観察を行った。結晶方位分布測定は走査 型電子顕微鏡 (Scanning Electron Microscope: SEM) および電 子線後方散乱回折 (Electron backscattering Diffraction: EBSD)
法により行った，EBSD 法においては冷延材と焼鈍材の TD 断面中心部付近を測定した. 冷延材と焼鈍材の極点図, 冷延 材の転位密度を X 線回折装置 (X-ray diffraction: XRD)により 測定した.

\section{3. 結果および考察}

\section{1 加工硬化能の評価}

Fig. 2 にニオブと鉄の公称応力 - 公称ひずみ線図, 真応力 一真ひずみ線図を示す. Fig. 2(b)の真応力－真ひずみ線図か らニオブと鉄の応力と加工硬化率の関係を求めたものを Fig. 3 に示す. ニオブおよび鉄ともにひずみの増加とともに加工 硬化率は低下するが, 二オブは鉄に比べて加工硬化率の減少 が早いことが確認できた.

冷延材の圧延率とビッカース硬さの関係を Fig. 4 に示す. いずれの冷延材も圧延率の上昇に伴ってビッカース硬さが概 ね増大しているが，その増加率はニオブの方が鉄よりも小さ く, 引張試験の加工硬化率の結果と同様に, 高ひずみ域にお いてもニオブの加工硬化性が鉄と比較して小さいことを示し ている. 加工硬化性, すなわち変形応力は主に転位の内部応 力が支配的要因であるため, 転位の応力場の強さを決める弾
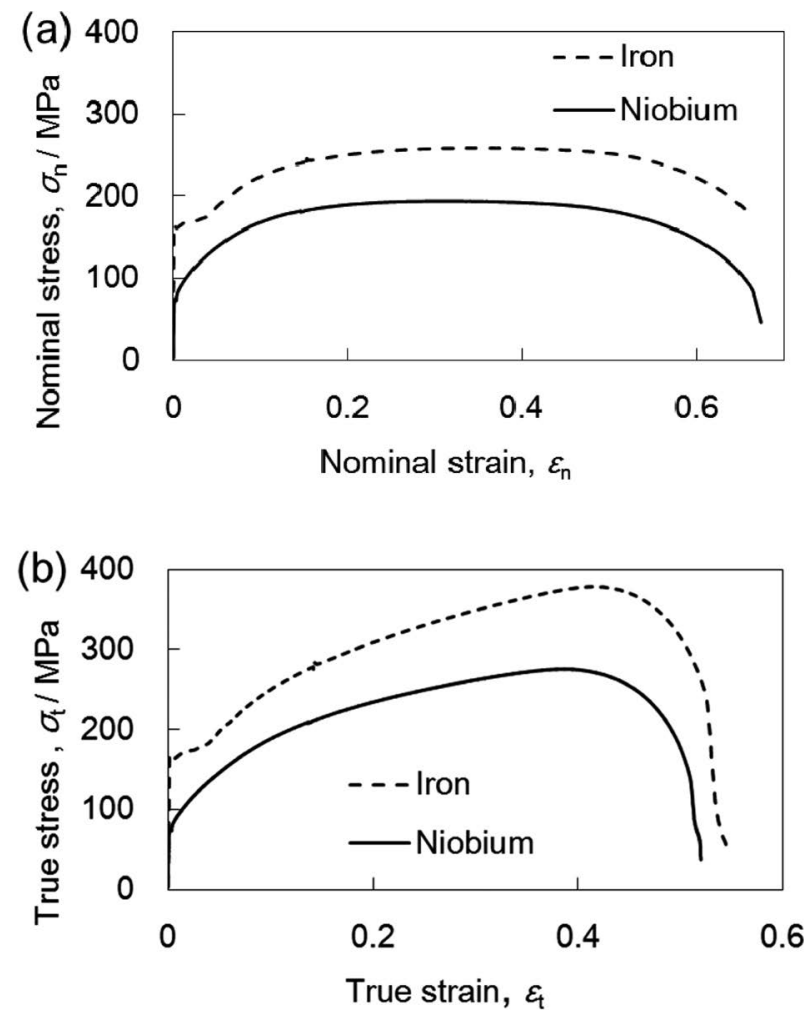

Fig. 2 (a) Nominal strain-nominal stress curves and (b) true stress-true strain curves of the as-received niobium and iron sheets.

Table 1 Chemical composition and purity of niobium specimen.

\begin{tabular}{|c|c|c|c|c|c|c|c|c|c|c|c|c|c|}
\hline \multicolumn{13}{|c|}{ Analytical element (ppm) } & \multirow{2}{*}{$\begin{array}{c}\text { RRR } \\
300 \mathrm{~K} / 9.5 \mathrm{~K}\end{array}$} \\
\hline & $\mathrm{C}$ & $\mathrm{O}$ & $\mathrm{N}$ & $\mathrm{Fe}$ & Mo & $\mathrm{Si}$ & $\mathrm{Ta}$ & $\mathrm{Ti}$ & W & $\mathrm{Zr}$ & $\mathrm{H}$ & $\mathrm{Nb}$ & \\
\hline Top & $<10$ & $<10$ & $<10$ & $<10$ & $<10$ & $<10$ & 80 & $<5$ & $<10$ & $<10$ & 2 & \multirow{2}{*}{ Bal. } & \multirow{2}{*}{464} \\
\hline Bottom & 10 & $<10$ & $<10$ & $<10$ & $<10$ & $<10$ & 110 & $<5$ & $<10$ & $<10$ & 1 & & \\
\hline
\end{tabular}




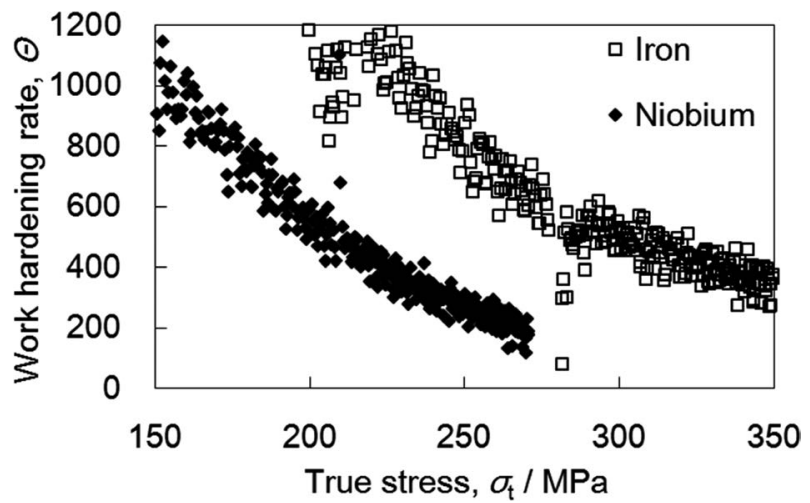

Fig. 3 Relationship between the work hardening rate and true stress of the as-received niobium and iron sheets.

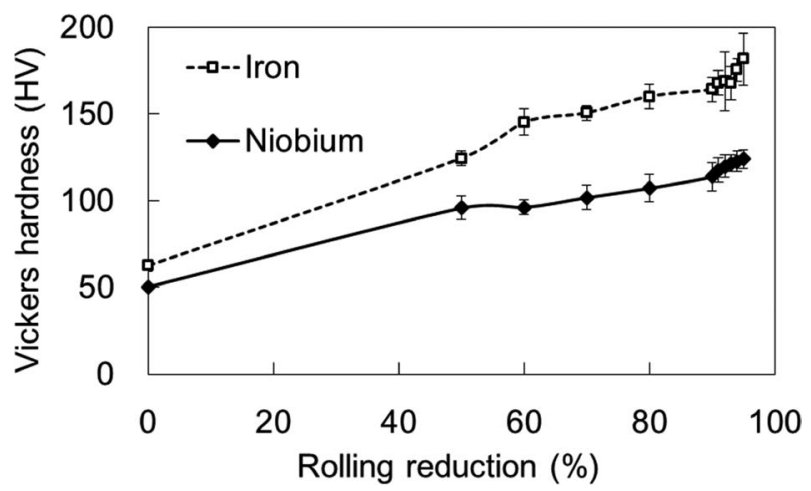

Fig. 4 Relationship Vickers hardness and rolling reduction in the as-rolled niobium and iron specimens.

性率 (ヤング率) と転位密度の増加率で決まる。そのため, 二 オブの低い加工硬化性は低い転位密度または弾性率に起因す ると考えらえる。

\section{2 再結晶挙動と組織変化}

冷延圧延後の焼鈍時の再結晶挙動を評価するために, 圧延 率60\%, 95\%時の冷延材を種々の温度で焼鈍熱処理を行った. 焼鈍材の各温度での熱処理後の硬さを Fig. 5 に示す. Fig. 5 (b)より圧延率 $95 \%$ の時，ニオブと鉄はそれぞれ $1073 \mathrm{~K}, 823$ $\mathrm{K}$ 付近で軟化が完了した。この軟化温度の差は融点に起因す ることが示唆される. 金属材料の再結晶温度は, 材料の融点 を $\mathrm{T}_{\mathrm{m}}$ として $0.4 \sim 0.5 \mathrm{~T}_{\mathrm{m}}$ であることが知られている. ニオブ

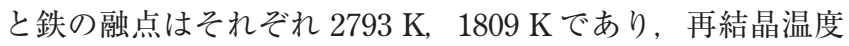
は 1117〜1397 K， 724～905 K であることが予想される ${ }^{11) . ~}$

Fig. 5 の軟化曲線から推定できる再結晶温度は概ねこの範囲 内であり，軟化開始温度の差は融点に大きく影響されること が確認できた. Fig. 5(a)より圧延率60\%の時, ニオブと鉄は それぞれ $1123 \mathrm{~K}, 873 \mathrm{~K}$ で軟化した。この場合も融点に応じ た軟化温度の差があった. しかしニオブの硬さは熱処理温度 の上昇とともに単調に減少し, 再結晶による典型的な急激な 軟化を示さなかった。このゆるやかな軟化挙動は鉄とは対照 的であった。圧延率 $60 \%$ ，95\%の冷延材の焼鈍過程における 組織写真を Fig. 6-9 に示す。鉄は軟化前の温度で伸長した組 織の中に再結晶核が生じ，それが徐々に加工組織を侵食し, 軟化後には等軸状の組織に変化していることが明確である. これに対してニオブの $60 \%$ 圧延では, 温度上昇とともに転位
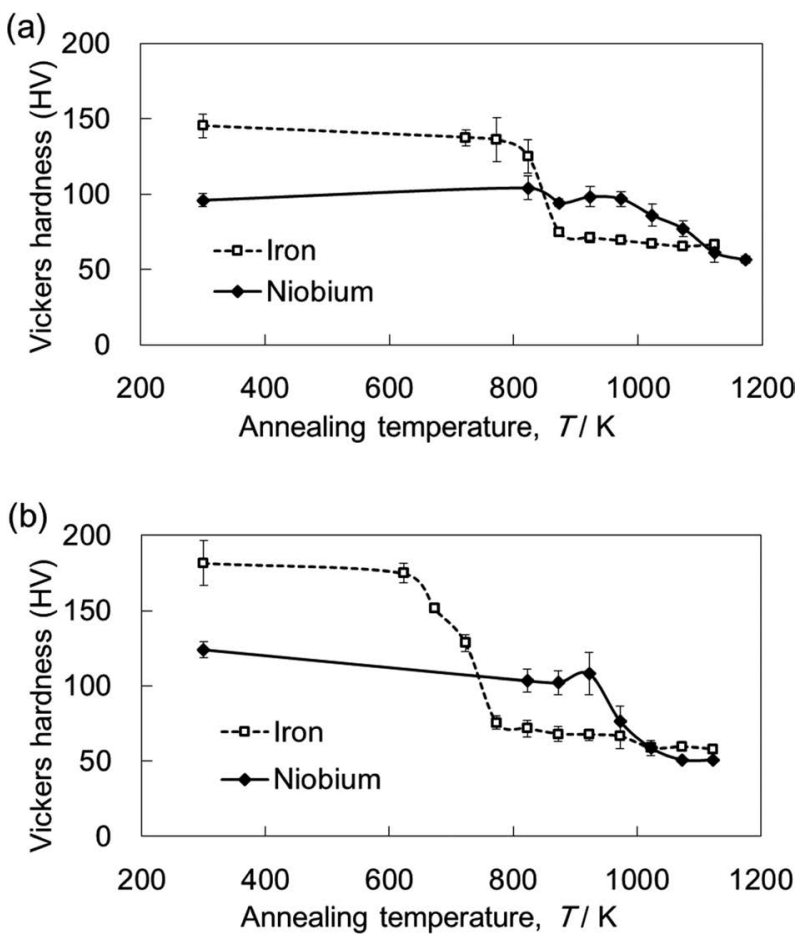

Fig. 5 Relationship between Vickers hardness and annealing temperature in the niobium and iron specimens after cold rolling with reduction of (a) $60 \%$ and (b) $95 \%$.

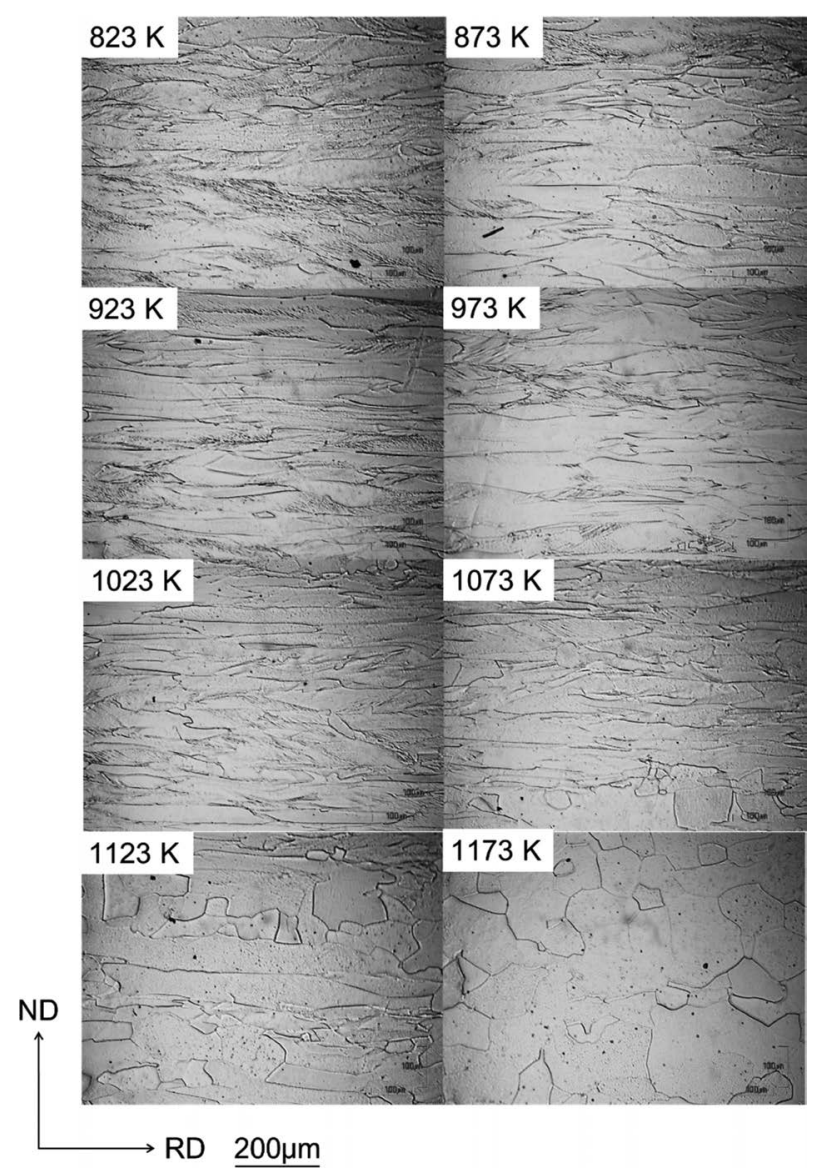

Fig. 6 Micrographs of the annealed niobium specimens after cold rolling with reduction of $60 \%$.

ピットが消失するとともに, 湾曲した結晶粒界が平面状に変 化し，ひずみが消失していくのが認識できるが，核形成と成 長が明確でなく，どこから再結晶が開始して終了したのかが， 


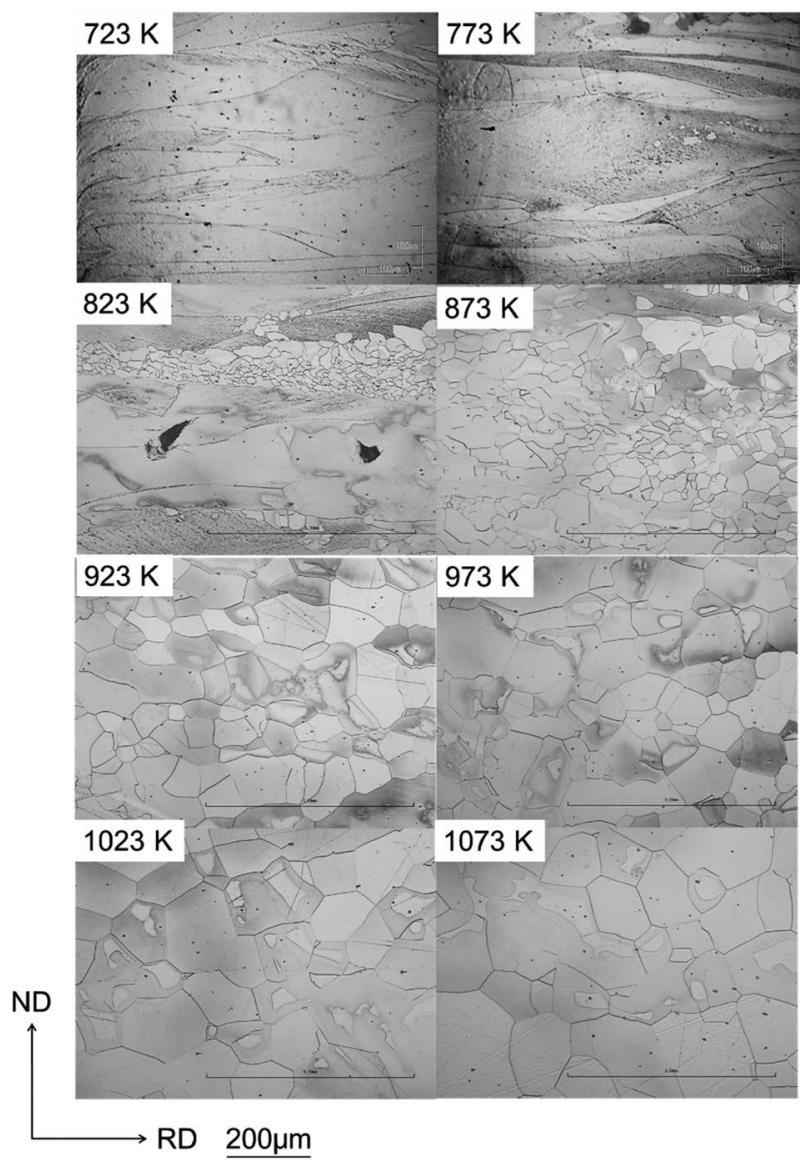

Fig. 7 Micrographs of the annealed iron specimens after cold rolling with reduction of $60 \%$.

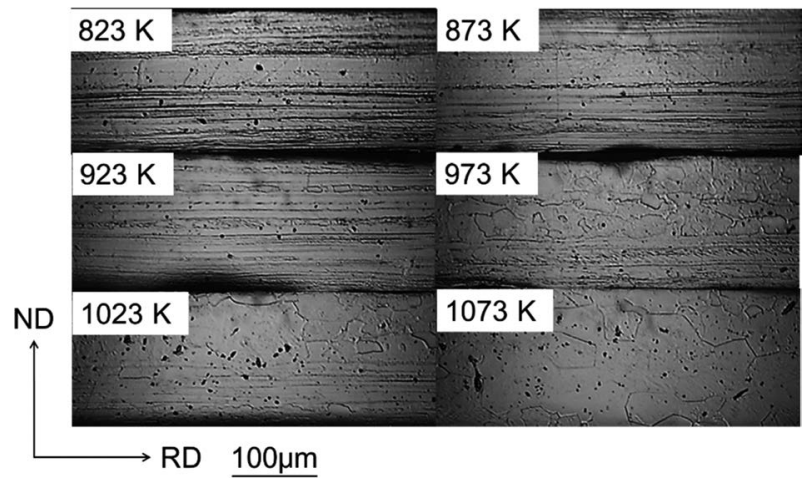

Fig. 8 Micrographs of the annealed niobium specimens after cold rolling with reduction of $95 \%$.

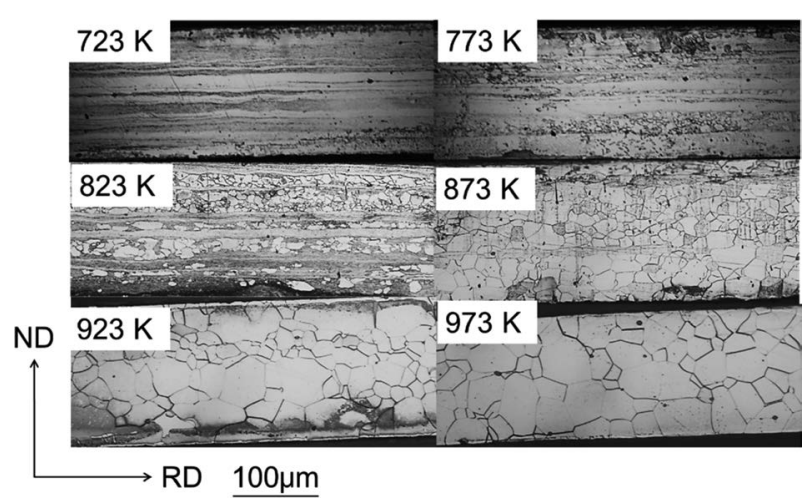

Fig. 9 Micrographs of the annealed iron specimens after cold rolling with reduction of $95 \%$.
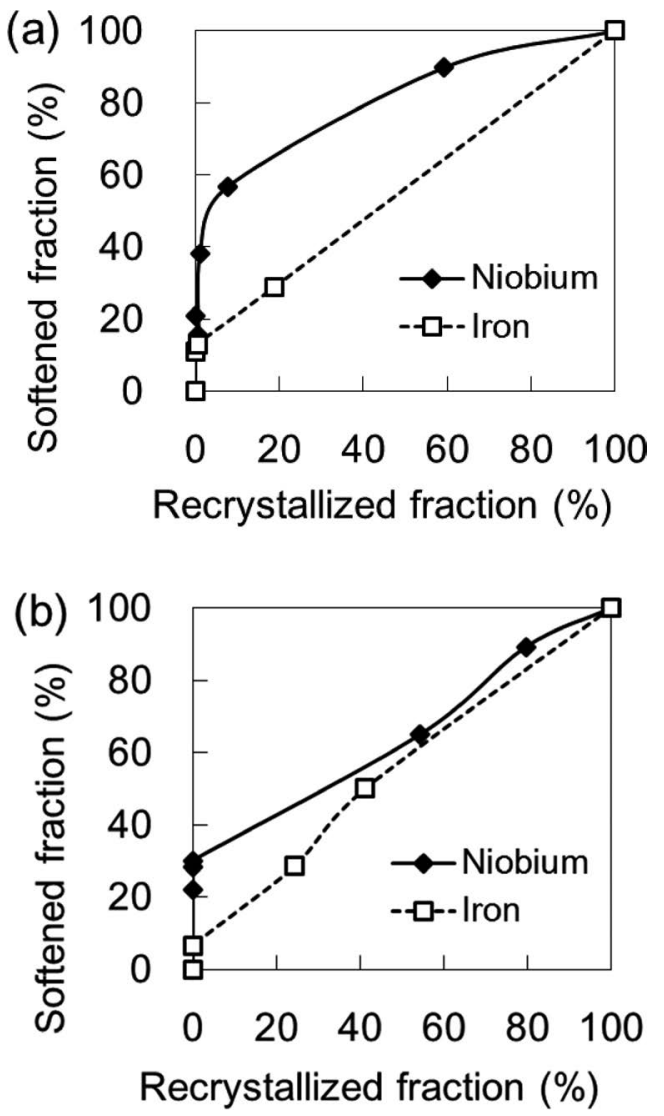

Fig. 10 Relationship between the softened fraction and the recrystallized fraction for the annealed niobium and iron specimens after cold rolling with reduction of (a) $60 \%$ and (b) $95 \%$.

光学顕微鏡写真からでは判断できない。 また，鉄に比べて伸 長した組織が焼鈍過程に扔いて多く残留する傾向が見られる。 ニオブの $90 \%$ 圧延では，加工組織と再結晶組織の顕著な変化 が確認された．冷延材の焼鈍過程に押ける軟化率と Fig. 6-9 から算出した再結晶率の関係を Fig. 10 に示す. 圧延率 $60 \%$ 冷 延材に打いて鉄は再結晶の進行に概ね対応して軟化している 一方で，ニオブには軟化初期では再結晶に先行して軟化のみ が進行する。つまりニオブは再結晶に先行して回復による軟 化が大きいことが示唆される。圧延率が95\%の泠延材の場合 では，60\%に比べてニオブは再結晶による軟化の程度が大き くなっているが，鉄に比べて回復による軟化の程度が高いこ とが明らかになった。

\section{3 集合組織の変化}

冷延材掞よび焼鈍材の結晶方位マップと逆極点図を Fig. 11 に示す．いずれの冷延材も優勢な方位は $<100>/ / \mathrm{ND}$ 方位, $<111>/ / \mathrm{ND}$ 方位であった。つまりニオブは鉄の圧延集合組 織と定性的に一致していることがわかった.

次に軟化後を見ると，圧延率 $60 \%$ ではニオブは鉄に比べて方 位のばらつきが少なく，圧延後の優先方位である $<100>/ / \mathrm{ND}$ 方位が残留していることがわかった．結晶方位マップから $<100>/ / \mathrm{ND}$ 方位は比較的粗大で伸延した結晶粒であること がわかる。 $<100>/ / \mathrm{ND}$ 方位は圧延安定方位で，転位密度が 低いために再結晶が生じにくく，熱処理後も初期方位を継承 して圧延に進展した結晶粒群として残留しやすい ${ }^{15)}$ ，二オブ 

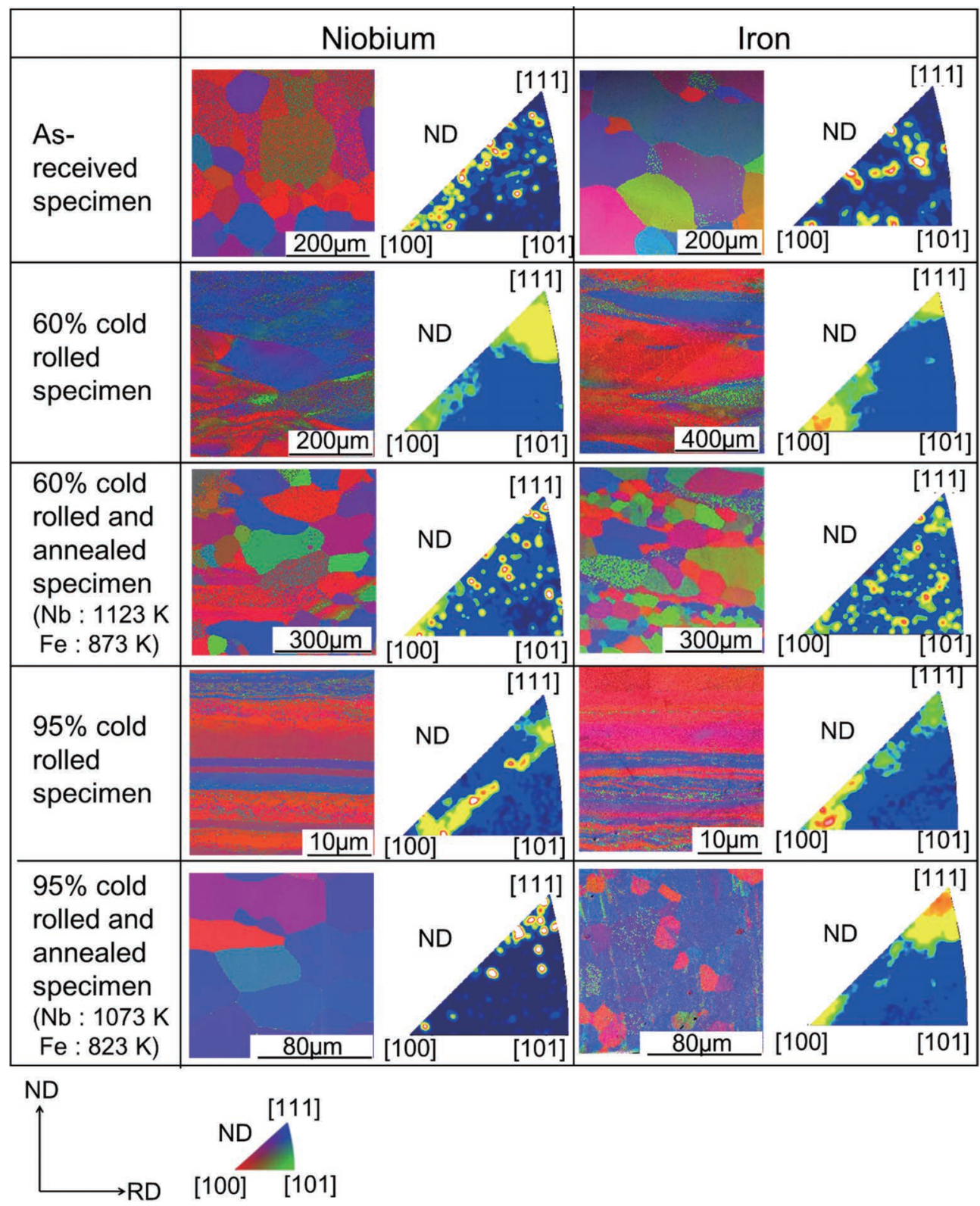

Fig. 11 Orientation image maps and invers pole figures of the as-received sheets, 60 and $95 \%$ cold rolled specimens and annealed specimens after 60 and $95 \%$ cold rolling.

は軟化とともに結晶方位の変化は見られるが, <100>//ND 方位結晶粒を中心に鉄に比べて方位が残留する傾向にある. 圧延率 $95 \%$ 焼鈍材の場合, ニオブと鉄は再結晶による方位変 化が確認された。高い加工度に打いてもニオブには回復によ る軟化が鉄に比べて高いことを 3.2 節で述べたが, 再結晶によ るく100>//ND 方位の減少またはランダム化が確認された.

Fig. 11 で示した SEM による EBSD 解析では位置情報が得 られるが，測定範囲が狭いため測定場所によるバラッキが問 題となる。 そこでX線回折を用いた極点図の解析を行った. 圧延率 $70 \%$ 冷延材，焼鈍材の $\{100\}$ 極点図を Fig. 12 に示す. 焼鈍前後で比較すると，ニオブは鉄に比べて $<100>/ / / \mathrm{ND}$ 方 位の結晶粒が多く残留する傾向にあり，EBSD 解析から示唆 された結果と同様の傾向を確認することができた。しかし， 結晶方位の変化は鉄と比較して小さいものの, ランダム化し ており，再結晶による方位変化は生じていると考えられる．

\section{4 ニオブの再結晶挙動}

再結晶の速さを決める因子は, 再結晶核の形成密度 (頻度) とその成長速さと考えることができる，再結晶核は方位差の 大きな転位セルと仮定すると，転位密度の増加により再結晶 核の形成密度は高くなると考えられる。再結晶核の成長速さ については未再結晶部と再結晶部の粒界の移動速度により決 定されると考えられる，粒界の移動速度 $v$ は，粒界移動の駆 動力 $P$, 粒界の移動度 $M$ を用いて以下の式で表される.

$$
v=M \cdot P
$$

駆動力 $P$ はひずみエネルギーであり，転位の自己エネルギー と転位密度の積に等しい。このように, 核形成密度や粒界移 動速度は転位密度の増加とともに高くなるはずであり，再結 晶前の加工組織の結晶粒径等に差異がないと仮定すると, ニ オブは鉄に比べて転位密度が低いことが予想される。

そこでXRDから得られるピーク值を用いてWilliamson-Hall 


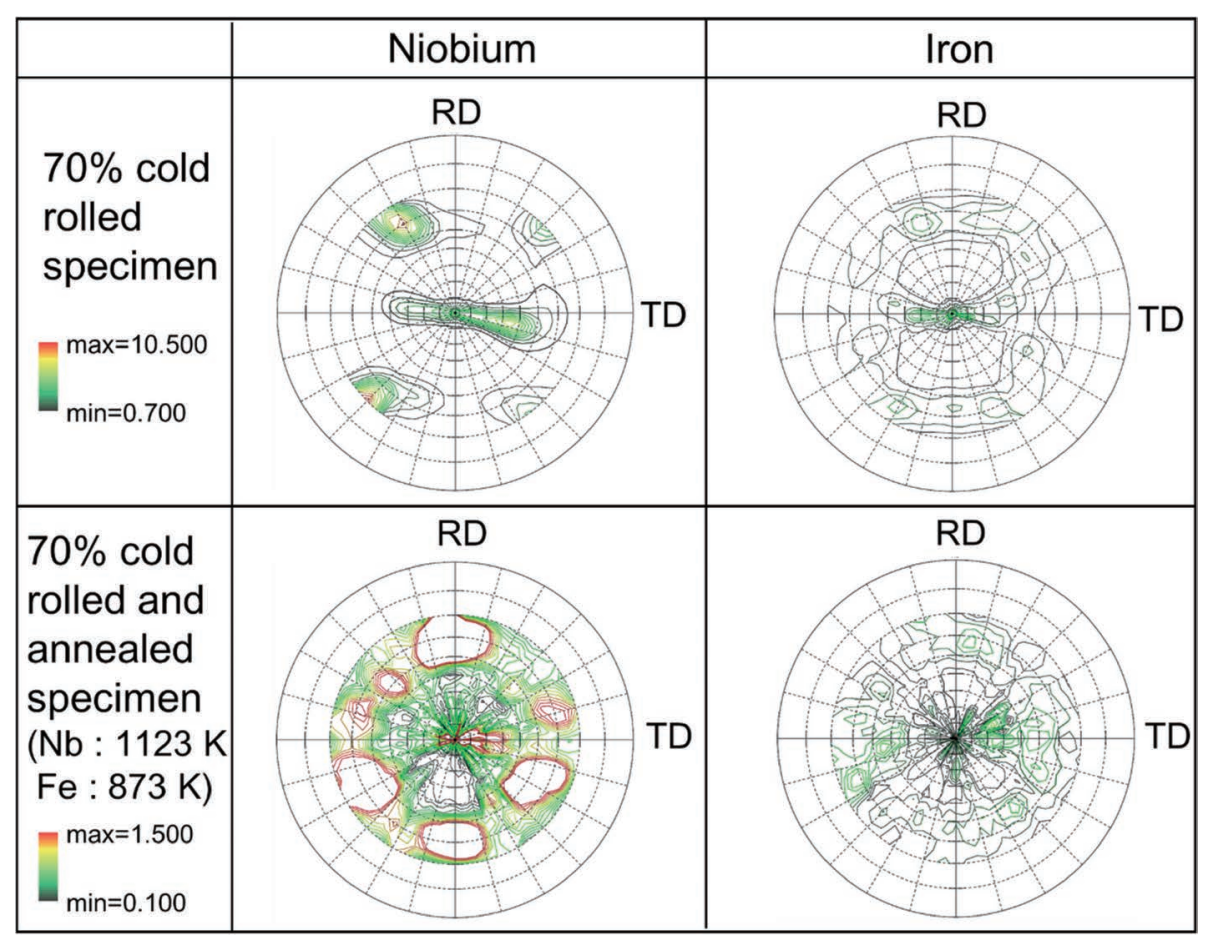

Fig. $12\{100\}$ pole figures of the cold rolled specimens with reduction of $70 \%$ and subsequently annealed specimens.

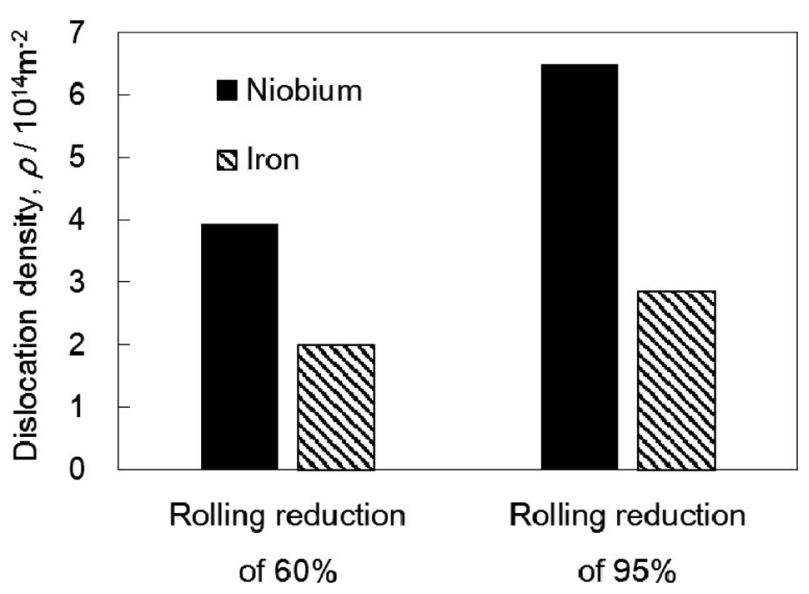

Fig. 13 Dislocation densities calculated by Williamson-Hall method in the specimens after cold rolling with reduction of $60 \%$ and $95 \%$.

法 ${ }^{16)}$ により冷延材の転位密度を算出した. Fig. 13 よりニオブ と鉄はいずれも圧延率の上昇に伴って転位密度が増加してい るが，同一のひずみで比較すると，予想に反してニオブは鉄 よりも転位密度が 2 倍程度高く, 転位が堆積しやすいことが わかった。これは, 緒言で述べたニオブのもつ低い弾性率に 起因することが推測される。弾性率が低いニオブでは転位間の 反発力が弱く, 交差すべりおよび転位の対消滅が制限される. これにより転位密度が高くなったことが考元られる。転位の 蓄積による総ひずみエネルギーは近似的に $\alpha \rho \mu b^{2},(\alpha, \mu, b, \rho$ はそれぞれ定数, 転位密度, 剛性率, バーガースベクトルの 大きさ)，と近似すると，ニオブの剛性率は鉄の約半分である が, 転位密度が 2 倍なので, 再結晶駆動力である加工後の総 ひずみエネルギーはほほ同レベルと考えることができる.

そこで, 粒界の移動速度 $v$ を決めるもう一つの因子である

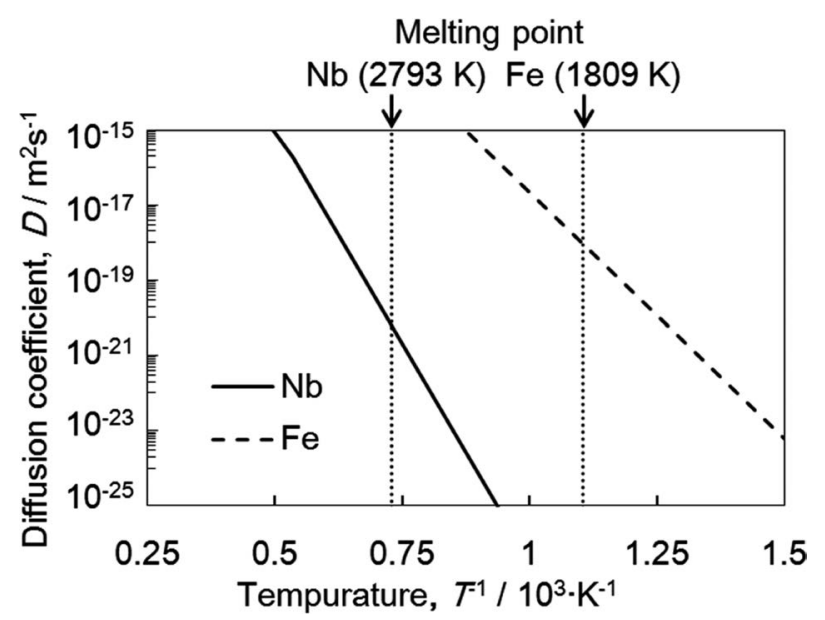

Fig. 14 Diffusion coefficient in an Arrehenius plot of the niobium and iron.

粒界の移動度 $M$ に着目した，粒界の移動度は拡散係数と粒界 性格で決まる。したがって鉄とニオブで粒界性格分布に大き な差はないと仮定すると拡散倸数が高い方が粒界移動度が高 く, 再結晶の進行が速くなると考えられる. Fig. 14 にニオブ と鉄の拡散係数をアレニウスプロットで表したグラフを示 す11). ニオブと鉄を同じ融点比で比較しても，鉄よりもニオ ブの拡散係数が低いことは明らかである. このことから, ニ オブは再結晶粒の粒界の移動度が小さくなることが考えられ る. ニオブは弾性率が低いことに起因して冷間圧延後の転位 密度が鉄に比べて高くなり，ひずみエネルギーは鉄との差は 小さい. しかし, 拡散倸数が低いことから粒界の移動度が小 さくなるため再結晶の進行速さが低くなることが示唆された. 


\section{4. 結論}

高純度ニオブと高純度鉄の冷間圧延後および焼鈍後の組 織・集合組織, 軟化挙動を調査した結果, 以下の知見を得た.

（1）冷間圧延において，ニオブは鉄に比べて硬さの上昇率 が低く，加工硬化が生じにくいことを確認した。

(2) 冷延圧延後，ニオブは鉄に比べて回復による軟化の割 合が大きく，焼鈍後も集合組織の変化が小さく，<100>//ND 方位で構成された圧延集合組織が残留する傾向が高い.

（3）ニオブは鉄に比べて弾性率が低いために冷間圧延後の 転位密度が約 2 倍高くなった。ニオブの弾性率は鉄の半分で あることを考えると, 再結晶の駆動力である総ひずみエネル ギーは両者に大きな差はないと考えられる。一方はニオブの 拡散係数は鉄に比べて低いことから，粒界の移動度が小さく なるため再結晶の進行が鉄に比較して遅くなり，回復により 軟化しやすいと考えられる.

本研究は国立研究開発法人新エネルギー・産業技術総合開 発機構 $(\mathrm{NEDO})$ の中堅・中小企業への橋渡し研究開発促進事 業の研究助成金により行われました。ここに謝意を表します。

\section{文献}

1) T. Nagata, N. Abe, H. Masui, S. Shinozawa, J. Nagakubo, H. Murakami, H. Inoue, M. Yamanaka and E. Kano: Proc. 16th KEK Mechanical Engineering Workshop, (High Energy Accel- erator Research Organization, 2015) pp. 77-80.

2) T. Nagata, N. Abe, S. Shinozawa, J. Nagakubo, H. Murakami, T. Tajima, H. Inoue and M. Yamanaka: Proc. 14th KEK Mechanical Engineering Workshop, (Particle Accelerator Society of Japan, 2013) pp. 77-80.

3) W. Singer: Hydrogen in Matter (AIP Conference Proceedings) 837 (AIP Publishing, 2006) pp. 51-63

4) W. Singer, H. Kaiser, X. Singer and G. Weichert: Proc. 10th Workshop on RF Superconductivity, (High Energy Accelerator Research Organization, 2001) pp. 170-176.

5) S. Balachandran, R. C. Elwell, D. Kang, R. E. Barber, T. R. Bieler and K. T. Hartwig: IEEE Transactions on Applied Superconductivity 23(2013) 7100904

6) H. F. G. Abreu, S. S. M. Tavares, S. S. Carvalho, T. H. T. Eduardo, A. D. S. Bruno and M. H. Prado da Siva: Mater. Sci. Forum 539-543(2007) 3436-3441.

7) K. T. Hartwig, J. Wang, D. C. Baars, T. R. Bieler, S. N. Mathaudhu and R. E. Barber: IEEE Transactions on Applied Superconductivity $\mathbf{1 7}$ (2007) $1305-1309$

8) M. Brochu, T. Yokota and S. Satoh: ISIJ Int. 37(1997) 872-877.

9) H.-C. Chao: Metall. Trans. 4(1973) 1183-1186.

10) C. S. Costa Viana, A. L. Pinto, F. S. Candido and R. G. Matheus: Mater. Sci. Technol. 22(2006) 293-300.

11) The Japan Institute of Metals and Materials: Metal Data Book (Kinzoku deta bukku), (Maruzen Publishing, Tokyo, 2010) p. 11, pp. $20-23$, p. 31

12) D. Baars, H. Jiang, T. R. Bieler, A. Zamiri, F. Pourboghrat and C. Compton: Applications of Texture Analysis, (The American Ceramic Society, 2008) pp. 391-398.

13) D. Baars, T. R. Bieler, K. T. Hartwig, H. Jiang, C. Compton and T. L. Grimm: JOM 59(2007) 50-55.

14) T. R. Bieler, N. T. Wright, F. Pourboghrat, C. Compton, K. T. Hartwig, D. Baars, A. Zamiri, S. Chandrasekaran, P. Darbandi, H. Jiang, E. Skoug, S. Balachandran, G. E. Ice and W. Liu: Physical Review Special Topics-Accelerators and Beams 13 (2010) 031002

15) N. Tsuji, T. Shinmiya, Y. Saito and M. Muraki: ISIJ Int. 38(1998) 380-389.

16) G. K. Williamson and R. E. Smallman: Philos. Mag. 1(1956) $34-46$. 